\title{
Meckel's Diverticulitis Causing Small Bowel Intussusception: A Case Report
}

\author{
Meckel Divertikülitine Bağli İnce Bağırsak İntususepsiyonu: Olgu Sunumu
}

\author{
DEdis Çolak \\ University of Health Sciences, Dr. Behçet Uz Child Disease and Pediatric Surgery Training and Research Hospital, Department of \\ Radiology, Izmir, Turkey
}

\begin{abstract}
Meckel's diverticulum (MD) is considered the most common congenital gastrointestinal malformation affecting $2 \%$ of the population. Complications including hemorrhage, diverticulitis, and intestinal obstruction occur in only $4 \%$ of patients with MD. This article presents the imaging findings of a small bowel intussusception caused by Meckel's diverticulitis in a 10-year-old girl with acute abdominal pain.
\end{abstract}

Keywords: Meckel's diverticulum, Meckel's diverticulitis, intussusception, intestinal obstruction.

\section{INTRODUCTION}

Meckel's diverticulum (MD) represents the most common gastrointestinal congenital malformation (1). The most frequent complications of $\mathrm{MD}$ are gastrointestinal hemorrhage, diverticulitis, and intestinal obstruction (1).To the best of our knowledge, the co-occurrence of Meckel's diverticulitis and small bowel obstruction in children have been reported only twice in English literature $(2,3)$.

This report shows the imaging findings of a small bowel intussusception caused by Meckel's diverticulitis in a 10-year-old girl with acute abdominal pain.

\section{CASE REPORT}

A ten-year-old girl who had undergone an appendectomy for acute appendicitis six months earlier, presented to the

\section{ÖZ}

Meckel divertikülü (MD), popülasyonun \%2'sinde görülen en yaygın doğumsal gastrointestinal anomalisidir. MD hastalarının sadece \%4'ünde kanama, divertikülit ve intestinal obstrüksiyon gelişir. Bu makale, akut karın ağrısı olan 10 yaşındaki kız olguda Meckel divertikülitine bağlı gelişen ince bağırsak intususepsiyonunun görüntüleme bulguları sunulmuştur.

Anahtar Kelimeler: Meckel divertikülü, Meckel divertiküliti, intususepsiyon, intestinal obstrüksiyon

hospital complaining of abdominal pain and vomiting for the past five days.

Herabdomenwas distendedandshehadatendernessover the periumbilical region. The laboratory investigations showed mild anemia with an increased C-reactive protein value and white blood cell count. The urine analysis was normal. There were no significant findings in the chest X-ray. Abdominal radiographic imaging revealed no signs of pneumoperitoneum or dilated small-bowel loops with air-fluid levels.

The ultrasonographic (US) image demonstrated a target sign characteristic of intussusception caused by a blindended segment of a thick-walled bowel (Figure 1A). Surrounding soft tissue hyperechogenicity, reactive lymph nodes, and free intra-abdominal fluid was suggestive of associated inflammation. 
The contrast-enhanced abdominal CT images showed a fluid-filled, blind-ending intestinal structure with mural enhancement (Figure 1B).

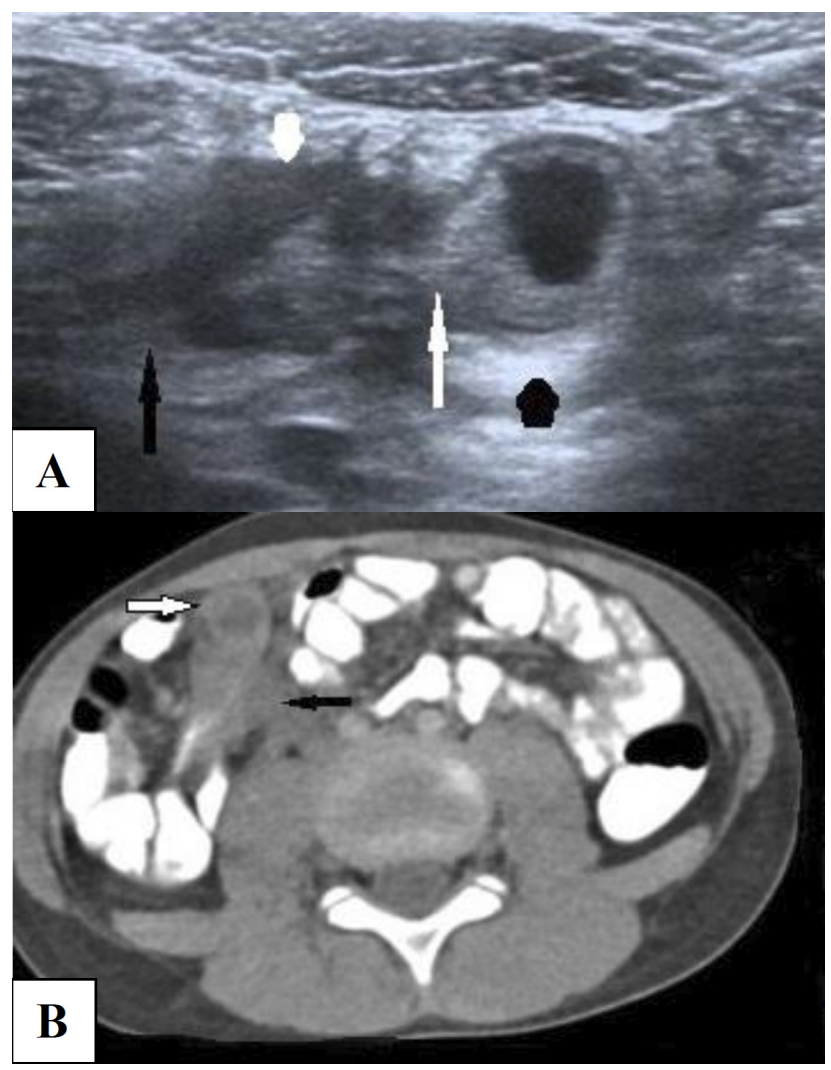

Figure 1. A. An ultrasound view shows the appearance of a blind ending and thick-walled bowel segment (white arrow) in continuity with the terminal ileum (black arrow) surrounded by soft tissue hyperechogenicity (black arrowhead) and free fluid (white arrowhead). B. Contrast-enhanced abdominal CT axial image shows a blind-ending intestinal structure (white arrow) with reactive lymph nodes (black arrow).

The intraoperative findings revealed an ileo-ileal intussusception due to inflamed MD located $15 \mathrm{~cm}$ from the ileocecal valve. A segmental small bowel and MD resections with consecutive anastomosis were performed. Histopathology confirmed the diagnosis of Meckel's diverticulitis containing heterotopic gastric mucosa and inflammatory cells around the diverticulum. The postoperative period was uneventful, and the patient was discharged 6 days after the surgery. Informed consent was signed by the patient's father.

\section{DISCUSSION}

Meckel's diverticulum (MD) occurs as a result of incomplete obliteration of the omphalomesenteric duct (1). MD is generally recognized by the 'rule of twos' affecting $2 \%$ of the population, located two feet $(60 \mathrm{~cm})$ from the ileocecal valve, usually two inches $(5 \mathrm{~cm})$ long, and may contain gastric or pancreatic ectopic tissues (4).
MD is often asymptomatic; however $15 \%$ of patients more than four years old, $77 \%$ of patients aged one month to two years, and $85 \%$ of neonates develop symptoms due to complicated MD (2). The most common complications of MD are gastrointestinal bleeding, intestinal obstruction, and diverticulitis. Neoplasm is rare. Gastrointestinal bleeding is the most frequently encountered complication of MD in children $(5,6)$. It occurs due to the acid secretion from the ectopic gastric tissue leading to peptic ulceration of the ileal mucosa (6). Meckel's diverticulitis occurs more frequently in adult patients (1). Complicated diverticulitis may be associated with perforation, formation of abscess, fistula, or bowel obstruction due to inflammatory adhesions (1-3). MD may act as a lead point causing ileo-vitelline, ileo-ileal, and ileocolic types of intussusceptions (6). MD tumors are very rare $(1,2)$.

Radiologic diagnosis of complicated MD can be difficult, especially when the diagnosis is not initially suspected (6). One systematic review reported that $40 \%$ of fifty patients with MD had a preoperative diagnosis of acute appendicitis (6). Ultrasonography (US) should be the first step imaging modality for evaluation of the complicated MD in children. Inflamed MD is usually presented as a cystlike structure in the periumbilical region or right lower quadrant. A sonographic study by Daneman et al. reported that inflamed MD has a thicker and more irregular wall with increased vascularisation than that found in an enteric duplication cyst (7).

An intravenous contrast-enhanced abdominal CT is recommended in cases of high clinical suspicion and negative findings on US. Although it is difficult to determine the MD on $C T$, a blind-ending intestinal structure with mural enhancement and surrounding fat stranding are highly suggestive for Meckel's diverticulitis (8). A water-soluble oral contrast-enhanced abdominal CT facilitates the diagnosis of an abscess, fistula, or perforation due to Meckel's diverticulitis. Oral contrast media should be avoided in cases of acute gastrointestinal hemorrhage as it may obscure the active contrast extravasation from the site of bleeding (8). Contrast material accumulation into the blind-ending digestive structure connected to the ileum suggests an active bleeding MD $(6,8)$.

Radionuclide studies based on Technetium-99m pertechnetate administration help identify the ectopic gastric mucosa in the MD. A review considering children with MD reported that the complicated MD was 2.3 times more likely to be diagnosed with $\mathrm{CT}$ than with scintigraphy (8).

To the author's knowledge, only two cases regarding the co-occurrence of Meckel's diverticulitis and small bowel obstruction in children have been published to date. The CT images of a Meckel's diverticulitis causing small bowel obstruction were first described by Shelat et al. (2). Kumar 
et al. reported the abdominal X-ray findings of intestinal obstruction caused by inflamed MD (3). This report shows the images of three non-invasive radiological techniques of the small bowel intussusception caused by Meckel's diverticulitis in a child.

\section{CONCLUSION}

The present case suggests that MD should be considered as a possible cause for intussusception in children above two years of age. An early diagnosis is essential to ensure favorable outcomes in children with MD.

\section{ETHICAL DECLARATIONS}

Informed Consent: Written informed consent was obtained from all participants who participated in this study.

Referee Evaluation Process: Externally peer-reviewed.

Conflict of Interest Statement: The authors have no conflicts of interest to declare.

Financial Disclosure: The authors declared that this study has received no financial support.

Author Contributions: All of the authors declare that they have all participated in the design, execution, and analysis of the paper, and that they have approved the final version.

\section{KAYKANLAR}

1. Skarpas A, Siaperas P, Zoikas A, et al. Meckel's Diverticulitis. A rare cause of small bowel obstruction. J Surg Case Rep 2020;2020:rjaa339.

2. Shelat VG, Kelvin Li K, Rao A, Sze Guan T. Meckel's diverticulitis causing small bowel obstruction by a novel mechanism. Clin Pract 2011;1:e51.

3. Kumar KJ, Kumar MG, Shyamala P, Kumar MP. Meckel's diverticulitis causing intestinal obstruction in a 3 month old infant. J Res Med Sci 2013;18:826.

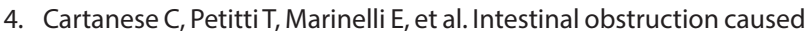
by torsed gangrenous Meckel's diverticulum encircling terminal ileum. World J Gastrointest Surg 2011;3:106-9.

5. Lin XK, Huang XZ, Bao XZ, Zheng N, Xia QZ, Chen CD. Clinical characteristics of Meckel diverticulum in children: $A$ retrospective review of a 15-year single-center experience. Medicine (Baltimore) 2017;96 :e7760.

6. Moore T, Johnston AO. Complications of Meckel's diverticulum. Br J Surg 1976;63:453-4.

7. Daneman A, Lobo E, Alton DJ, Shuckett B. The value of sonography, CT and air enema for detection of complicated Meckel diverticulum in children with nonspecific clinical presentation. Pediatr Radiol 1998;28:928-32.

8. Olson DE, Kim YW, Donnelly LF. CT findings in children with Meckel diverticulum. Pediatr Radiol 2009;39:659-63; quiz 766-7. 